\title{
The Effect of Transformational Leadership and Non-Physical Work Environment on Employee Performance with Job Satisfaction as Intervening Variables at PT. Perkebunan Nusantara V during COVID-19 Pandemic
}

\author{
Vena Revlina Emelias Sembiring1, Ritha F Dalimunthe ${ }^{2}$, \\ Beby Karina F Sembiring ${ }^{3}$ \\ ${ }^{1,2,3}$ Faculty Economics and Business, University of Sumatera Utara, Medan, Indonesia. \\ Corresponding Author: Vena Revlina Emelias Sembiring
}

DOI: https://doi.org/10.52403/ijrr.20220154

\begin{abstract}
The objective of the research is to analyze of transformational leadership and non-physical work environment of employee performance through job satisfaction at PT. Perkebunan Nusantara V. This type of research is causal with a quantitative approach. The population in this study were all employees of main office, totaling 503 employees. Used primary and secondary data which are obtained through documentation study and questions list. Taken by using simple random sampling. The data are analyzed with structural equation modeling (SEM) using SmartPLS 3.0 version. The results demonstrated that transformational leadership had positive and significant effect on employee satisfaction, non-physical work environment positive and hadn't have significant effect on employee satisfaction, transformational leadership had positive and significant effect on job satisfaction, non-physical work environment had positive and significant effect on job satisfaction, job satisfaction had positive and significant effect on employee satisfaction. Transformational leadership indirectly had had positive and significant effect on employee performance through job satisfaction and nonphysical work environment had positive and significant effect on employee satisfaction through job satisfaction.
\end{abstract}

Keywords: Transformational leadership, nonphysical work environment, job satisfaction, employee performance

\section{INTRODUCTION}

The world is currently being shocked by the emergence of a virus originating from Wuhan, China which first appeared in November 2019. This virus is called the Corona Virus. All countries are trying to break the Covid-19 chain by making new regulations related to this virus, such as the implementation of a lockdown or work from home. The Covid-19 pandemic has forced people, including individuals in organizations, to adapt to new habits and behaviors such as implementing health protocols, maintaining distance, not crowding, and even leaving the house only if there is an urgent situation. The impact of the pandemic that is most affected is human resources. Human resources are a very important factor in running the organization in achieving its goals. Without human resources, other resources will be idle and less useful. The results of the work of human resources, both individuals and groups, both qualitatively and quantitatively in an effort to achieve company goals, are commonly referred to as employee performance. Employee performance is a very influential 
Vena Revlina Emelias Sembiring et.al. The effect of transformational leadership and non-physical work environment on employee performance with job satisfaction as intervening variables at PT. Perkebunan Nusantara V during COVID-19 pandemic.

thing for the development of a company. Good employee performance will make it easier for the company to develop. But because of the pandemic, many companies are having a hard time surviving.

PT. Perkebunan Nusantara V experienced an increase in performance during the Covid-19 pandemic, while almost all companies experienced a decline due to activity restrictions in accordance with established health protocols and coincided in the same year there was a change of leadership at PT. Perkebunan Nusantara V which resulted in increased company performance. The company's leaders from 2019 until now have been closer to employees by providing inspiration and support so that employees can develop more for the achievement of company goals, so that employees have a sense of trust, admiration, loyalty, and respect for the leadership. According to Ritaudin and Mukhsin (2018) there are several factors that cause employee performance to increase, namely transformational leadership, work environment, and job satisfaction. According to Robbins (2017). Transformational leadership is a leader who pays attention to the issues and development needs of each follower. Transformational leaders change followers' awareness of problems by helping them view old problems in new ways. The next factor that affects employee performance is the nonphysical work environment. According to Sedarmayanti (2015) the non-physical work environment is a condition that occurs related to work relationships, both working relationships with superiors and working relationships with fellow co-workers, or working relationships with subordinates. The next factor that affects performance is job satisfaction. According to Afandi (2018) job satisfaction is a positive attitude from the workforce including feelings and behavior towards their work through the assessment of one job as a sense of appreciation in achieving one of the important values of the job.

\section{LITERATURE REVIEW Employee performance}

Mangkunegara (2017) performance is the result of work in quality and quantity achieved by an employee in carrying out his duties in accordance with the responsibilities given to him. In addition, according to Lizan (2017), employee performance is defined as the ability of employees to do certain things. According to Agustina et al. (2019) employee performance needs to be considered because employee self-confidence and self-esteem greatly affect work results. With confidence, employees feel able to complete their tasks effectively. According to Kawiana et al., (2020) it is formulated that the factors that can affect employee performance are transformational leadership, work environment and job satisfaction.

\section{Job satisfaction}

Job satisfaction is basically something that is individual. Each individual has a different level of satisfaction according to the system that applies to him. According to Kaswan (2017), job satisfaction is the result of employees' perceptions of how well their work provides things that are considered important. Meanwhile, according to Wibowo (2016), job satisfaction is a general attitude towards one's work that shows the difference between the number of awards workers receive and the amount they believe they should receive. According to Robbin (2016) job satisfaction is a general attitude towards one's work that shows the difference between the number of awards received by workers and the amount that workers believe they should receive. According to Robbins and Judge (2015) defines job satisfaction as positive feelings about work as a result of evaluating the characteristics of the job.

Based on the five definitions that have been put forward by experts, it can be concluded that job satisfaction is the feeling of happiness of employees towards their work which is produced by their own efforts 
Vena Revlina Emelias Sembiring et.al. The effect of transformational leadership and non-physical work environment on employee performance with job satisfaction as intervening variables at PT. Perkebunan Nusantara V during COVID-19 pandemic.

and which is supported by things outside of themselves, on work conditions, work results, and work itself. When employees join an organization, they bring with them a set of wants, needs, desires, and past experiences that combine to form job expectations. Job satisfaction shows the match between a person's expectations that arise and the rewards provided by the job.

\section{Transformational leadership}

Transformational leadership is one type of leadership in which the leader provides inspiration and support to employees to further develop in order to achieve goals. Transformational leaders also change followers' awareness of problems by helping them look at old problems in new ways and they are able to excite, excite, and inspire followers to put in extra effort to achieve group goals. Transformational leadership is a condition in which followers feel trust, admiration, loyalty, and respect for the leader and they are motivated to do more than they originally expected (Bass, 2013; Yuki, 2015). Leaders change and motivate followers by making them more aware of the importance of task outcomes, persuading them to put the interests of their team or organization above their personal interests, and activating their higher-order needs. Wibowo (2017) says that transformational leadership is a leadership perspective that explains leaders change a team or organization by creating, communicating, and modeling a vision for the organization or work unit and inspiring employees to strive to achieve that vision.

Based on the definitions that have been put forward by the experts, the researcher concludes that transformational leadership is a leadership style in which the leader inspires and supports a lot of employees, and can create a sense of trust, admiration, loyalty and respect for the leader.

\section{Non-Physical Work Environment}

The non-physical work environment is a condition related to the emotional relationship between leaders and employees, and emotional relationships between fellow employees that can affect employee performance. Sedarmayanti (2017) argues that the non-physical work environment is all conditions related to work relationships, both with superiors and relationships with fellow coworkers. Suwondo and Sutanto (2015) argue that the non-physical work environment is an interaction or relationship between employees and leaders.

Based on the definition put forward by experts, it is concluded that the nonphysical work environment is the state of the employee's workplace environment in the form of a harmonious work atmosphere, meaning that there is a relationship or communication between subordinates and superiors (vertical relationships) and relationships between fellow employees (horizontal relationships). With a harmonious working atmosphere and communication, employees will feel comfortable at work so that the work they do can be carried out properly, effectively and efficiently.

\section{MATERIALS \& METHODS}

This research is a causal research with a quantitative approach. This study aims to describe or describe the nature (characteristics) of a situation or object of research carried out starting from the collection and analysis of quantitative data and statistical testing. The variables connected in this study are independent variables, namely transformational leadership variables (X1) and non-physical work environment (X2), the dependent variable is employee performance $(\mathrm{Y})$, and the intervening variable is job satisfaction (Z). This research was conducted at PT. Nusantara V Plantation Jalan Rambutan. The population in this study were all employees who work at the head office of PT. The Nusantara V plantation in Pekanbaru has 503 employees. The sampling method used is simple random sampling, namely the sampling of the population is carried out randomly without 
Vena Revlina Emelias Sembiring et.al. The effect of transformational leadership and non-physical work environment on employee performance with job satisfaction as intervening variables at PT. Perkebunan Nusantara V during COVID-19 pandemic.

regard to the strata that exist in the population. Sampling was carried out using the Slovin formula. Based on calculations using the Slovin formula, it is concluded that the sample of respondents in this study was 84 employees who worked at the head office of PT. Perkebunan Nusantara V. The data analysis technique used to test the hypothesis in this study is descriptive analysis and PLS-SEM analysis.

\section{RESULT}

\section{Respondents' Descriptive Results}

Table 1 Characteristics of Respondents

\begin{tabular}{|c|c|c|c|c|c|c|}
\hline Data & & $\mathbf{f}$ & $(\%)$ & Data & $\mathbf{f}$ & $(\%)$ \\
\hline \multicolumn{2}{|c|}{ Gender } & & & Education & & \\
\hline & Male & 78 & 92,9 & Senior High School & 6 & 7,1 \\
\hline & Female & 6 & 7,1 & D3 & 4 & 4,8 \\
\hline \multicolumn{2}{|l|}{ Age } & & & S1 & 66 & 78,6 \\
\hline & $21-30$ & 15 & 17,9 & $\mathrm{~S} 2$ & 8 & 9,5 \\
\hline & $31-40$ & 25 & 29,8 & Work Division & & \\
\hline & $41-50$ & 28 & 33,3 & Engineering and Processing & 13 & 15,4 \\
\hline & $>50$ & 16 & 19 & Plant & 14 & 16,7 \\
\hline \multicolumn{2}{|c|}{ Length of work } & & & Hukum & Law & 7,1 \\
\hline & $1-10$ & 21 & 25 & Finance & 8 & 9,5 \\
\hline & $11-20$ & 24 & 28,6 & HR & 9 & 10,7 \\
\hline & $21-30$ & 28 & 33,3 & company secretary & 9 & 10,7 \\
\hline & $>31$ & 11 & 13,1 & Internal Control Unit & 10 & 11,9 \\
\hline & & & & Strategic Planning and Business Engineering & 6 & 7,1 \\
\hline & & & & Procurement & 9 & 10,7 \\
\hline \multicolumn{2}{|c|}{ Note: $n=84$} & & & & & \\
\hline
\end{tabular}

Table 1 presents a description of the sample, where the majority of respondents are male (92.9\%). This shows that respondents with male sex are more dominant than women. This is triggered by various factors, including: as known by PT. Perkebunan Nusantara V is engaged in the palm oil industry and processing, so the company requires employees to go to the field and it is physically needed because the terrain they face tends to be difficult. In addition, the majority of respondents are 4150 years old $(33.3 \%)$. In this case, employees who work at PT. Perkebunan Nusantara $\mathrm{V}$ is a senior employee who already has a lot of experience and the majority of these employees have worked between 21-30 years, which consists of the position of Head of Sub-Division and Head of Division who work directly under the auspices of the leadership. The majority of respondents worked in the plant work division consisting of 14 respondents $(16.7 \%)$ and the engineering and processing work division as many as 13 respondents $(15.4 \%)$. This is because PT. Perkebunan Nusantara V works in the commodity of oil palm plantations along with the processing into semi-finished goods, so that employees work more and are placed in the work division.

\section{Data Analysis Results}

The following table presents the path coefficient values and P-Values values for testing the significance of the direct effect and indirect effect.

Tabel 2 Path Coefficients (Direct Effect and Indirect Effect)

\begin{tabular}{|c|c|c|c|}
\hline & Original Sample $(\mathbf{O})$ & P Values & Conclusion \\
\hline Transformational Leadership -> Employee Performance & 0,343 & 0,040 & Accepted \\
\hline Non-Physical Work Environment -> Employee Performance & 0,140 & 0,362 & Rejected \\
\hline Transformational Leadership -> Job Satisfaction & 0,353 & 0,023 & Accepted \\
\hline Non-Physical Work Environment -> Job Satisfaction & 0,523 & 0,001 & Accepted \\
\hline Happy Satisfaction-> Employee Performance & 0,434 & 0,001 & Accepted \\
\hline Transformational Leadership -> Job Satisfaction ->Employee Performance & 0,153 & 0,035 & Accepted \\
\hline
\end{tabular}


Vena Revlina Emelias Sembiring et.al. The effect of transformational leadership and non-physical work environment on employee performance with job satisfaction as intervening variables at PT. Perkebunan Nusantara V during COVID-19 pandemic.

\section{DISCUSSION}

\section{The Effect of Transformational Leadership on Employee Performance}

Based on the results of hypothesis testing, it is shown that transformational leadership has a positive and significant effect on employee performance at PT. Perkebunan Nusantara V. This is evidenced by the path coefficient value of 0.343 with a significant value of $0.040<0.05$, meaning that transformational leadership has a positive and significant effect on the performance of PT. Perkebunan Nusantara $\mathrm{V}$. So that the results of this hypothesis test are accepted. The results of this study indicate a positive and significant relationship between transformational leadership and employee performance. The better the implementation of transformational leadership by the leadership will be in line with the increase in employee performance. Leaders must be able to be role models and have charisma so that the motivation and support given to employees can be carried out for the achievement of goals. One form of support and motivation by PT. Perkebunan Nusantara $\mathrm{V}$ to improve employee performance during the pandemic, the company created a special website, namely OliDoSS for employees of PT. Perkebunan Nusantara $\mathrm{V}$ and create discussion groups for each division on the WhatsApp application. It aims to establish communication, provide support and work motivation and the leadership conducts evaluations every week.

The results of transformational leadership research on employee performance at PT. Perkebunan Nusantara $\mathrm{V}$ is in accordance with research conducted by Dung and Hai (2020) "The Effect of Transformational Leadership and Job Satisfaction on Commitment to Organizational Change: A ThreeComponent Model Extension Approach"; Budiwati et al. (2020) "The Influence of Transformational Leadership Styles and Compensation on Employee Performance Mediated by Job Satisfaction"

\section{The Effect of Non-Physical Work Environment on Employee Performance}

Based on the results of hypothesis testing, it is shown that the non-physical work environment has a positive and insignificant effect on employee performance at PT. Perkebunan Nusantara $\mathrm{V}$. This is evidenced by the path coefficient value of 0.140 with a significant value of $0.362>0.05$, meaning that the non-physical work environment has a positive and insignificant effect on the performance of PT. Perkebunan Nusantara V employees. So the results of this hypothesis test are rejected.

The results of this study indicate that the non-physical work environment has no effect on employee performance. Good relations between superiors and subordinates, as well as relations with fellow employees do not affect employee performance. The results of this study are in accordance with the opinion of Norianggono, et al (2014) which states that the non-physical work environment in the form of the relationship between superiors and employees or fellow employees does not affect employee performance because employee performance is still assessed individually so that social relations in the company do not really affect performance. employee.

\section{The Effect of Transformational Leadership on Job Satisfaction}

Based on the results of hypothesis testing, it is shown that transformational leadership has a positive and significant effect on job satisfaction at PT. Perkebunan Nusantara V. This is evidenced by the path coefficient value of 0.353 with a significant value of $0.023<0.05$, meaning that transformational leadership has a positive and significant effect on job satisfaction at PT. Perkebunan Nusantara V. So that the results of this hypothesis test are accepted.

The results of this study indicate a positive and significant relationship between transformational leadership and job satisfaction. The support and motivation 
Vena Revlina Emelias Sembiring et.al. The effect of transformational leadership and non-physical work environment on employee performance with job satisfaction as intervening variables at PT. Perkebunan Nusantara V during COVID-19 pandemic.

given by the leadership to employees creates job satisfaction for employees. Leaders also provide solutions if employees are facing problems. The results of this study are in accordance with the opinion of Yuki (2009) the extent to which a leader is called transformational is measured by the influence of leadership on his followers. Followers i.e. employees feel trust, admiration, loyalty, and respect for the leader and feel motivated to take action for the common good.

The results of transformational leadership research on job satisfaction at PT. Perkebunan Nusantara V is in accordance with research conducted by Budiwati et al. (2020) "The Influence Of Transformational Leadership Styles And Compensation On Employee Performance Mediated By Job Satisfaction"; Ritaudin and Mukhsin (2018) "The Influence of Transformational Leadership and Work Environment on KSK Performance with Job Satisfaction as an Intervening Variable in Banten Province"

\section{The Effect of Non-Physical Work Environment on Job Satisfaction}

Based on the results of hypothesis testing, it is shown that the non-physical work environment has a positive and significant effect on job satisfaction at PT. Perkebunan Nusantara V. This is evidenced by the path coefficient value of 0.523 with a significant value of $0.001<0.05$, meaning that the non-physical work environment has a positive and significant effect on job satisfaction at PT. Perkebunan Nusantara V. So the results of this hypothesis test are accepted.

The results of this study indicate that there is a positive and significant relationship between the non-physical work environment and job satisfaction of PT. Perkebunan Nusantara V. This shows that the relationship between the leadership and employees as well as fellow employees is well established due to mutual respect for each other, and the absence of discrimination in front of leaders and fellow employees. So that it creates a sense of comfort in carrying out the duties and objectives of the company.

The results of research on nonphysical work environment on job satisfaction at PT. Perkebunan Nusantara V is in line with research conducted by Ramli (2019) "Work Environment, Work Motivation and Organizational Culture in Influencing Teachers Performance"; Taheri et al. (2020) "Impact of Working Environment on Job Satisfaction"; Raziq et al. (2015) "Impact of Working Environment on Job Satisfaction".

\section{The Effect of Job Satisfaction on Employee Performance}

Based on the results of hypothesis testing, it is shown that job satisfaction has a positive and significant effect on employee performance at PT. Perkebunan Nusantara $\mathrm{V}$. This is evidenced by the path coefficient value of 0.434 with a significant value of $0.001<0.05$, meaning that job satisfaction has a positive and significant effect on the performance of PT. Perkebunan Nusantara $\mathrm{V}$ employees. So the results of this hypothesis test are accepted.

The results of this study indicate that there is a positive and significant relationship between job satisfaction and employee performance. It can be said that when employees feel that the provision of facilities, health insurance and pension funds, allowances and salaries as well as promotions from the company is as expected, employees will also try to give their best as a reward to the company so as to improve employee performance. Vice versa, when employees feel dissatisfied and even disappointed, the employee's performance will decrease. The results of this study are in accordance with the opinion of Herawati (2018) that job satisfaction is a positive feeling felt by employees in the work environment, a feeling that creates a sense of enthusiasm and motivation to provide even better things to the company. This proves that when job 
Vena Revlina Emelias Sembiring et.al. The effect of transformational leadership and non-physical work environment on employee performance with job satisfaction as intervening variables at PT. Perkebunan Nusantara V during COVID-19 pandemic.

satisfaction increases, employee performance also increases.

\section{The Effect of Transformational Leadership on Employee Performance through Job Satisfaction}

Based on the results of hypothesis testing, it is shown that transformational leadership has a positive and significant effect on employee performance through job satisfaction. This is evidenced by the path coefficient value of 0.153 with a significant value of $0.035<0.05$, meaning that job satisfaction mediates between transformational leadership on employee performance at PT. Perkebunan Nusantara $\mathrm{V}$. So that the results of this hypothesis test are accepted.

The results of this study indicate a positive and significant relationship between transformational leadership on employee performance through job satisfaction. This means that there is a significant increase in job satisfaction triggered by support and motivation from the leadership, so that it has a positive impact on the company through increasing employee performance. The results of this study are in accordance with the opinion of Ritaudin (2018) where employee performance cannot increase instantly, it must go through a long process. Transformational leadership is considered an important influence on job satisfaction, because the leader provides inspiration and support to employees. Thus, employees are satisfied with the attention, support and guidance in order to improve employee performance.

\section{The Effect of Non-Physical Work Environment on Employee Performance through Job Satisfaction}

Based on the results of hypothesis testing, it is shown that the non-physical work environment has a positive and significant effect on employee performance through job satisfaction. This is evidenced by the path coefficient value of 0.227 with a significant value of $0.045<0.05$, meaning that job satisfaction mediates the relationship between non-physical work environment and employee performance at PT. Archipelago Plantation. So that the results of this hypothesis test are accepted.

The results of this study indicate a positive and significant relationship between the non-physical work environment on employee performance through job satisfaction at PT. Perkebunan Nusantara V. When the leadership enforces equality for employees, employees will compete fairly in their work. The existence of equality will make employees feel satisfied which has a positive impact on employee performance. Employees will compete to get promotions according to work experience and to get appreciation from the leadership. So, employees will also compete to provide the best for the company so that employee performance will also increase. The results of this study are in accordance with the opinion of Ramli (2019) which states that when the relationship between the leader and employees and fellow employees is good, a positive emotional relationship will be established so that it can create a sense of security, comfort and can motivate each other to work harder so that performance increases and company goals are achieved.

\section{CONCLUSION}

Based on the results of the study it can be concluded that:

1. Transformational Leadership has a positive and significant effect on Employee Performance at PT. Perkebunan Nusantara V.

2. Non-Physical Work Environment has a positive and insignificant effect on Employee Performance at PT. Perkebunan Nusantara V.

3. Transformational Leadership has a positive and significant effect on Job Satisfaction at PT. Perkebunan Nusantara V.

4. Non-Physical Work Environment has a positive and significant effect on Job Satisfaction at PT. Perkebunan Nusantara V. 
Vena Revlina Emelias Sembiring et.al. The effect of transformational leadership and non-physical work environment on employee performance with job satisfaction as intervening variables at PT. Perkebunan Nusantara V during COVID-19 pandemic.

5. Job satisfaction has a positive and significant effect on employee performance at PT. Perkebunan Nusantara V.

6. Transformational Leadership has a positive and significant effect on Employee Performance through Job Satisfaction at PT. Perkebunan Nusantara V.

7. Non-Physical Work Environment has a positive and significant effect on Employee Performance through Job Satisfaction at PT. Perkebunan Nusantara V.

\section{Acknowledgement: None}

\section{Conflict of Interest: None}

\section{Source of Funding: None}

\section{REFERENCES}

1. Afandi, P. (2018). Teori, Konsep dan Indikator Manajemen Sumber Daya Manusia. Edisi Pertama. Yogyakarta: Nusa Media.

2. Agustina, Ritha F. Dalimunthe, dan Sukaria Sinulingga. (2019). The Effect of Recruitment, Training and Placement of The Performance of Employee in PT Astra International Tbk, Toyota Auto 2000 SM. Raja Medan. Europan Journal of Human Resource Management Studies, 3 (1).

3. Akbar, S. (2018). Analisa Faktor-Faktor yang Mempengaruhi Kinerja Karyawan. Jurnal Ilmu Administrasi Negara dan Bisnis, $2(1)$.

4. Al-Omari, Khaled dan Haneen Okasheh. (2017). The Influence of Work Environment on Job Performance: A Case Study of Engineering Company in Jordan. International Journal of Applied Engineering Research, 12 (24).

5. Azizah, Juwita dan Amik Mitra Gama. (2017). Pengaruh Gaya Kepemimpinan dan Motivasi Terhadap Kinerja. Jurnal Manajemen, 3 (1).

6. Budiwati, Sjri Nova, Eko Heri, Limgiani, dan Suharto. (2020). The Influence of Transformational Leadership Style and Compensation on Employee Performance Mediated by Job Satisfaction. International Journal SSRG, 7.

7. Bobo, Jose. (2019). Pengaruh Kepemimpinan Transformasional, Motivasi Kerja dan Kepuasan Kerja Terhadap Kinerja, dengan Komitmen Organisasi Sebagai Variabel Mediasi Pada PT. Intan Pariwara Klaten. Tesis: Universitas Sanata Dharma.

8. Carvalho, Adelina da Cruz, I Gede Riana dan Augusto de C. Soares. (2020). Motivation on Job Satisfaction and Employee Performance. Journal of Management.

9. Dwi, Bambang, Hamidah (2016). "Pengaruh Lingkungan Kerja Fisik dan Lingkungan Kerja Non Fisik Terhadap Kepuasan Kerja dan Kinerja Karyawan (Studi Pada PT. Telkom Indonesia Witel Jatim Selatan Malang)". Jurnal 40 (1)

10. Dasio, Rini. (2017). Pengaruh Lingkungan Kerja Fisik dan Lingkungan Kerja NonFisik Terhadap Kinerja Karyawan dengan Kepuasan Kerja Sebagai Variabel Intervening Pada PT. Texco Indonesia. Diponegoro Journal of Management, 6 (4).

11. Dung, Luu Tien dan Phan Van Hai. (2020). The Effect of Transformational Leadership and Job Satisfaction on Commitment to Organitational Change: A ThreeComponent Model Extension Approach. The South East Asian Journal of Management, 14 (1).

12. Edison, Emron, Yohny Anwar, dan Imas Komariyah. (2018). Manajemen Sumber Daya Manusia. Strategi dan Perubahan dalam Rangka Meningkatkan Kinerja Pegawai dan Organisasi. Bandung: Alfabeta.

13. Erawati, Kadek Nonik, Ni Wajan Sitiari, dan Ni Luh Putu Indiani. (2019). The Effect of Stress and Working Environment on Employee Performance through Morivation Mediation: A Case Study on International Restaurant in Badung Bali. Jurnal Ekonomi dan Bisnis Jagaditha, 6 (1).

14. Fakih, M. (2013). Analisis Gender dan Transformasional Sosial. Yogyakarta: Pustaka Pelajar.

15. Firmansyah, Ade, Haris Maupa, Idrus Taba, dan Hardiyono. (2020). The Effect of Work Motivation, Work Environment, and Work Discipline on Employees Performance of Samsat Office Makassar. Hasanuddin Journal of Business Strategy, 2 (2).

16. Ghozali, Imam. (2015). Aplikasi Multirelative dengan Program IBM SPSS 
Vena Revlina Emelias Sembiring et.al. The effect of transformational leadership and non-physical work environment on employee performance with job satisfaction as intervening variables at PT. Perkebunan Nusantara V during COVID-19 pandemic.

23. Semarang: Badan Penerbit Universitas Diponegoro.

17. Hartanti, Rina. (2019). Kontribusi Work Environment dan Job Satisfaction Sebagai Multi Mediasi Terhadap Job Performance. Jurnal Manajemen dan Pemasaran Jasa, 12 (1).

18. Herawati, Heny. (2018). Analisis Pengaruh Gaya Kepemimpinan dan Budaya Organisasi Terhadap Kepuasan Kerja Serta Dampaknya pada Kinerja Karyawan Pada PT. Kimia Farma Jakarta. Commerce Jurnal Ilmiah Politeknik Piksi Input Serang, 6 (2).

19. Hidayat, Rahmad, Teddy Chandra dan Harry P. Panjaitan. (2018). Influence Of Organizational Culture, Work Motivation, and Leadership Style on Job Satisfaction and Employee Performance at Gas Station in Rokan Hilir. Jurnal Ekonomi.

20. Hughes, R. L, Ginnett R. C, dan Curphy. (2012). Leadership: Memperkaya Pelajaran dari Pengalaman. Edisi Ketujuh. Jakarta: Salemba Humanika.

21. Ilyas, Muhajir. (2014). Analisis Pengaruh Gaya Kepemimpinan dan Budaya Organisasi Terhadap Kepuasan Kerja Untuk Meningkatkan Kinerja Karyawan PT. Dok \& Perkapalan Kodja Bahari. Jurnal Sains Pemasaran. XII.

22. Kasmir. (2016). Manajemen Sumber Daya Manusia: Teori dan Praktik. Jakarta: Rajawali Pers.

23. Kaswan. (2017). Psikologi Industri \& Organisasi. Bandung: Alfabeta.

24. Kawiana, I Gede Putu, I Gete Riana, I Gede Rihayana, dan I Nyoman Rasmen Adi. (2020). How Transformational Leadership Intensify Employee Performance Mediating by Job Satisfaction. Jurnal Ilmiah Manajemen.

25. Kishen, Tantri Yanuar Rahmat, Syah Rina Anindita. (2020). The Transformational Leadership Effect on Job Satisfaction and Job Performance. Journal of Multidisciplinary Academic.

26. Kusumadewi, Ni Putu Rista, I Nengah Sudja dan I Wayan Sujana. (2018). The Influence of Leadership Style, Work Environment on Job Satisfaction and Employee Performance at PT. Kharisma Multi Lintas Cemerlang. International Journal of Contemporary Research and Review.

27. Lestary, Lyta dan Harmon. (2017). Pengaruh Lingkungan Kerja Terhadap
Kinerja Karyawan. Jurnal Riset Bisnis \& Investasi, 3 (2).

28. Lubis, Sartika Marina, Ritha F. Dalimunthe, Elisabet Siahaan. (2019). The Effect of Learning Organizations, Achievement Motivation through Work Environment as a Moderating Variable on Job Satisfaction of Temporary Employees (Non Medical) in the Administration Service of North Sumatera University Hospital Medan, Indonesia. Europan Journal of Human Resource Management Studies, 3 (1).

29. Luthans, Fred. (2011). Organizational Behavior $12^{\text {th }}$ Ed. New York: McGraw-Hill

30. Lutfi, Mohammad dan Siswanto. (2018). A Transformational Leadership and It's Implication on Employee Performance through Organizational Culture and Motivation. Jurnal Bisnis dan Manajemen.

31. Mangkunegara, A. P. (2017). Manajemen Sumber Daya Manusia Perusahaan. Bandung: PT. Remaja Rosdakarya.

32. Norianggono, Hamid, dan Ruhana. (2014). Pengaruh Lingkungan Kerja Fisik dan Non Fisik Terhadap Kinerja Karyawan (Studi Pada Karyawan PT. Telkom Area III Jawa Bali Nusra di Surabaya). Jurnal Administrasi Bisnis 8 (2).

33. Nurhuda, Amy, Sigit Sardjono, dan Wulan Purnamasari. (2019). Pengaruh Kepemimpinan Transformasional, Disiplin Kerja, Lingkungan Kerja Terhadap Motivasi dan Kinerja Karyawan Rumah Sakit Anwar Medika. Jurnal Ekonomi Manajemen.

34. Octaviannand, Ramona, Nurmala K. Pandjaitan, dan Sadikin Kuswanto. (2017). Effect of Job Satisfaction and Motivation Towards Employee's Performance in XYZ Shipping Company. Journal of Education and Practice, 8 (8).

35. Pawirosumarto, Suharno, Purwanto Katijan dan Rachman Gunawan. (2016). The Effect of Work Environment, Leadership Style, and Organizational Culture Towards Job Satisfaction and Its Implication Towards Employee Performance in Parador Hotels and Resorts, Indonesia. International Journal of Law and Management, 59 (6).

36. Poltak, Lizan. (2017). Manajemen Sumber Daya Manusia. Jakarta: Bumi Aksara

37. Prabowo, Thoni Setyo, Noermijati, dan Dodi Wirawan Irawanto. (2018). The Influence of Transformational Leadership and Work Motivation on Employee 
Vena Revlina Emelias Sembiring et.al. The effect of transformational leadership and non-physical work environment on employee performance with job satisfaction as intervening variables at PT. Perkebunan Nusantara V during COVID-19 pandemic.

Performance Mediated by Job Satisfaction. Journal of Applied Management, 16 (1).

38. Puni, Albert, Ibrahim Mohammed, dan Emmanuel Asamoah. (2018). Transformational Leadership and Job Satisfaction: The Moderating Effect of Contingent Reward. Leadership \& Organizational Development Journal.

39. Putra, G. Ngurah Suteja dan I Gusti Ayu Manuati Dewi. (2019). Effect of Transformational Leadership and Organizational Culture on Employee Performance Mediated by Job Motivation. International Research Journal of Management, 6 (6).

40. Putri, Elok Mahmud, Vivin Maharani Ekowati, Achmad Sani Supriyanto dan Zaim Mukaffi. (2019). The Effect of Work Environment on Employee Performance Through Work Discipline. International Journal of Research Granthaalayah, 7 (4).

41. Rafia, Retno, Achmad Sudiro, Sunaryo. (2020). The Effect of Transformational Leadership on Employee Performance Mediated by Job Satisfaction and Employee Engagement. International Journal of Business, Economic and Law, 21 (5).

42. Rahayu, Adriansyah. (2014). Hubungan Antara Kemandirian terhadap Stategi Masalah Ditinjau Dari Jenis Kelamin. Journal of Phychology.

43. Ramli, Abdul Haeba. (2019). Work Environment, Job Satisfaction and Employee Performance in Health Services. Business and Enterpreneurial Review.

44. Ritaudin, Didin dan Moh. Mukhsin. (2018) Pengaruh Kepemimpinan Transformasional dan Lingkungan Kerja Terhadap Kinerja KSK Dengan Kepuasan Kerja Sebagai Variabel Intervening Pada BPS Provinsi Banten. Jurnal Riset Bisnis dan Manajemen Tirtayasa, 2 (2).

45. Robbin, S. P dan Judge Timothy. (2015). Perilaku Organisasi. Edisi Keenam Belas. Jakarta: Salemba Empat.

46. __ dan Mary Coulter (2018). Management, Jilid 1 Edisi 13, Alih Bahasa: Bob Sabran dan Devri. Jakarta: Erlangga.

47. Rorong, Syutrika Vergie (2016). The Impact of Physical Work Environment Toward Employee Performance at PT. Bank Negara Indonesia Manado. Journal EMBA.

48. Rozarie, C. R. D. (2017). Manajemen Sumber Daya Manusia. Jakarta: Negara Kesatuan Republik Indonesia.
49. Saputra, I Gede Ade Eka dan I Gusti Ayu Dewi Adyani. (2017). Pengaruh Gaya Kepemimpinan dan Budaya Organisasi Terhadap Kepuasan Kerja Karyawan. Jurnal Manajemen.

50. Sedarmayanti. (2015). Manajemen Sumber Daya Manusia. Bandung: Refika Aditama.

51.

(2017). Manajemen

Perkantoran Modern. Bandung: CV. Mandar Maju.

52. Sitepu, Fahriani Astuti, Ritha F. Dalimunthe, dan Beby K. F. Sembiring. (2020). Pengaruh Lingkungan Kerja Fisik dan Lingkungan Kerja Non-Fisik Terhadap Kinerja Karyawan Melalui Kepuasan Kerja Pada PT. MNC Sky Vision Medan. Tesis: Universitas Sumatera Utara.

53. Sitorus, Christy Gomgom Ebenezer, RR. Erlina, dan Nova Mardiana. (2019). The Impact of Compensation, Transformational Leadership, and Employee Satisfaction Toward Employee Performance. Journal of Business Studies and Management.

54. Sugiono. (2017). Metode Penelitian Kuantitatif, Kualitatif dan R \& D. Bandung: Alfabeta.

55. Supriadi, Anitra. (2020). Pengaruh Lingkungan Kerja Non Fisik terhadap Kinerja Karyawan PT. Salim Surya Phone di Samarinda. Borneo Student Research. 1 (3).

56. Suryani. (2019). Pengaruh Lingkungan Kerja Non Fisik Dan Komunikasi Terhadap Kinerja Karyawan Pada PT. Bangkit Maju Bersama di Jakarta. Jurnal Ilmiah, Manajemen Sumber Daya ManusiaI. 2(3)

57. Suwondo, D. I dan Sutanto. (2015). Hubungan Lingkungan Kerja, Disiplin Kerja, dan Kinerja Karyawan. Jurnal Manajemen dan Kewirausahaan, 17 (2).

58. Syardiansyah, Abdul Latief, Muhammad Nur Daud, Windi, dan Agus Suharyanto. (2020). The Effect of Job Satisfaction and Organizational Culture on Employee Performance of The Royal Hotel in East Aceh District. Budapest International Research and Critics Institute, 3 (2).

59. Syofiana Yani, Ritha F. Dalimunthe, dan Prihatin Lumbanraja. (2018). Analisis Pelatihan Kompensasi Intrinsik dan Lingkungan Kerja Non Fisik Terhadap Komitmen Organisasi (Studi Pada Lembaga Penjamin Mutu Pendidikan Provinsi Sumatera Utara). Talenta Publisher, 1, 214225. 
Vena Revlina Emelias Sembiring et.al. The effect of transformational leadership and non-physical work environment on employee performance with job satisfaction as intervening variables at PT. Perkebunan Nusantara V during COVID-19 pandemic.

60. Tanjaya. (2019) Pengaruh Lingkungan Kerja Fisik dan Lingkungan Kerja Non Fisik Terhadap Kinerja Karyawan Bagian Produksi PT. Wira Internusa NiagaBandung. Jurnal Ilmiah Manajemen.

61. Taheri, Rafia Hasan, Md. Shipon Miah, dan Md. Kamaruzzaman. (2020). Impact of Working Environment on Job Saftisfaction. Europan Journal of Business and Management Research, 5 (6).

62. Turnip, Wenna Junianta. (2020). Effect of Motivation and Work Environment on Employee Performance of PT. XYZ. Journal of Management, 10 (2).

63. Vanjery, Dicky Ari. (2016). Pengaruh Motivasi dan Gaya Kepemimpinan Terhadap Kinerja Pegawai pada Biro Umum Sekretariat Jendral Kementrian Dalam Negeri. Tesis : Universitas Prof. DR. Moestopo Jakarta.

64. Wibowo. (2016). Manajemen Kinerja. Jakarta: Rajawali Press.

65. _ (2017). Manajemen Kerja. Edisi Kelima. Depok: PT. Raja Grafindo Persada.

66. Widyandi, Anak Agung Dwi, Ni Putu Ayu Sintya Saraswati dan I Negah Basma Wijaya. (2019). The Mediating Role of Turnover Intention on The Relationship Between Job Satisfaction and Employee
Performance: Evidance from KSU Sinar Dana Mandiri Employees. International Journal of Applied Business \& International Management, 4 (3).

67. Wijaya, Andi dan Agustin HP. (2019). The Effect of Discipline, Motivation and Satisfaction on Employee Performance in Hotel. International Journal of Administration, Business and Management.

68. Wiliandari Yuli (2015). Kepuasan Kerja Karyawan. Jurnal urusan Pendidikan Ekonomi.

69. Yuki, G. (2015). Kepemimpinan dalam Organisasi. Edisi Ketujuh. Jakarta: PT. Indeks.

70. Zainal, V. R., Hadad, dan Ramly (2017). Kepemimpinan dan Perilaku Organisasi. Jakarta: PT. Raja Grafindo Persada.

How to cite this article: Vena Revlina Emelias Sembiring, Ritha F Dalimunthe, Beby Karina F Sembiring. The effect of transformational leadership and non-physical work environment on employee performance with job satisfaction as intervening variables at PT. Perkebunan Nusantara V during COVID-19 pandemic. International Journal of Research and Review. 2022; 9(1): 478-488. DOI: https://doi.org/10. 52403/ijrr.20220154 